\title{
Accumulation Studies at a High Elevation Glacier Site in Central Karakoram
}

\author{
Christoph Mayer, ${ }^{1}$ Astrid Lambrecht, ${ }^{1}$ Hans Oerter, ${ }^{2}$ Margit Schwikowski, ${ }^{3}$ \\ Elisa Vuillermoz, ${ }^{4}$ Nicola Frank, ${ }^{5,6}$ and Guglielmina Diolaiuti ${ }^{7}$ \\ ${ }^{1}$ Commission for Geodesy and Glaciology, Bavarian Academy of Sciences and Humanities, Alfons-Goppel Straße 11, \\ 80539 München, Germany \\ ${ }^{2}$ Alfred Wegener Institute, Helmholtz Centre for Polar and Marine Research, Bremerhaven, Am Handelshafen 12, \\ 27570 Bremerhaven, Germany \\ ${ }^{3}$ Paul Scherrer Institute, Labor für Radio- und Umweltchemie, 5232 Villigen, Switzerland \\ ${ }^{4}$ Associazione EvK2CNR, Via San Bernardino 145, 24126 Bergamo, Italy \\ ${ }^{5}$ Institut für Umweltsozialwissenschaften und Geographie, Albert-Ludwigs-Universität Freiburg, Werthmannstraße 4, \\ 79098 Freiburg, Germany \\ ${ }^{6}$ OECOS GmbH, Hamburg, Germany \\ ${ }^{7}$ Ardito Desio Earth Sciences Department, Università degli Studi di Milano, Via Mangiagalli 34, 20133 Milan, Italy
}

Correspondence should be addressed to Christoph Mayer; christoph.mayer@lrz.badw-muenchen.de

Received 4 July 2014; Accepted 26 August 2014; Published 17 September 2014

Academic Editor: Eduardo García-Ortega

Copyright (C) 2014 Christoph Mayer et al. This is an open access article distributed under the Creative Commons Attribution License, which permits unrestricted use, distribution, and reproduction in any medium, provided the original work is properly cited.

\begin{abstract}
The precipitation conditions in central Karakoram are investigated on the basis of snow samples from high elevated snow pits at Urdok glacier from 2006 and the analysis of atmospheric transport trajectories in combination with the general, large scale pressure distribution. Our analysis shows that accumulation at the high elevated regions of the central Karakoram is dominated by the west wind circulation (WWC). Incursions of the South Asian monsoon (SAM) occur sometimes during the summer months accompanied by strong precipitation but play a minor role for the total accumulation amount. Dust layers found in the snow pits show a rare earth elements signature which indicates that the dust very likely originates from the arid regions of western China and Central Asia. Our trajectory calculations based on NCEP/NCAR reanalysis data confirm that especially during late spring and early summer the westerly flow is redirected over the Tarim basin to reach central Karakoram from an East/Southeast direction. The preservation of the layer structure and the clear seasonal signals in the snow pits indicate that locations above $5200 \mathrm{~m}$ in central Karakoram will be suitable places for retrieving longer climate records from ice cores.
\end{abstract}

\section{Introduction}

In recent years the glaciers of the Hindukush-KarakoramHimalaya $(\mathrm{HKH})$ range receive more and more attention, because of their potential impact on the water balance of regions which undergo a very strong change in population and societal and economic development [1-3]. The water demand in these regions is growing at a high rate, while water resources are limited. In Europe, glaciers act in a favorite way for the human society by storing water during periods of low demand (reduced agricultural activity during winter) and releasing water by ice melt during the main crop season. For the northern regions of the Indian subcontinent the relation is not that simple, because of a rather large variation of climatic conditions from the West to the East. In the western regions of the Hindukush, the summer monsoon plays only a minor role, while the eastern part of the Himalaya in Nepal, Sikkim, and Bhutan is strongly influenced by the Indian monsoon, resulting in high precipitation rates during the summer months. Thus, ice melt and the humid season coincide in this region [4], while the western parts show rather arid conditions during the summer months. In 
addition to this major West-East gradient, the influence of the monsoon varies also in South-North direction, where the relative significance depends very much on the strength of the individual monsoon season. Particularly in the western part of the $\mathrm{HKH}$ range, the annual precipitation conditions depend on the interchange of the westerlies and the monsoon activity during the course of the year. During a weak summer monsoon the clear weather in the mountains can increase ice melt and thus runoff from the glaciers, while during strong monsoon activities accumulation in the high elevated glacier basins is enhanced and water is stored as snow and ice.

Glacier runoff in years of intense melt needs to be compensated by high accumulation during other periods in order to provide stable conditions. During the past decades this system has become clearly out of balance with accelerated glacier melt at least in parts of the $\mathrm{HKH}$ range. However, the Karakoram Range seems to be remarkably stable, with no significant trend of ice loss $[3,5,6]$. Information from this remote region is mainly based on satellite data which are a suitable basis for documenting the retreat or advance of ice covered areas, while detailed volume changes are difficult to quantify. The melt down of debris covered glacier tongues, for example, is not so easily detected by remote sensing data, while changes in the accumulation amount are almost impossible to monitor from space.

Estimates of the mass balance conditions therefore require local information. Air temperature to estimate ablation [7-9] and precipitation to assess accumulation [10, 11] are suitable parameters for a simple parameterization of glacier mass balance. Air temperature usually shows a rather homogeneous spatial distribution on a regional scale, where the variation with altitude is much larger than the horizontal variability. The vertical lapse rate can be approximated by some assumptions about the general conditions in the atmosphere [12]. In contrast, precipitation is event driven and can change strongly within short distances. For example, intensive advective precipitation can occur in high elevations, while the low elevation valleys nearby experience no precipitation at all. Therefore air temperature information from weather stations can be used for mass balance estimates even distances farther away from the glacier, while accumulation conditions need at least to be described on a regional scale and at the appropriate elevation level.

Unfortunately almost no high elevation weather stations exist in the Karakoram. In addition, precipitation measurements are difficult and usually not representative for solid precipitation. Also field measurements of accumulation on glaciers are very scarce in the Karakoram and are basically restricted to the snow lake region of the upper Biafo glacier [13]. Most accumulation basins are situated between 4800 and $7000 \mathrm{~m}$, where no weather stations exist at all in the entire region. This demonstrates the need for obtaining more information about the accumulation conditions, to improve investigations on the mass balance conditions of this important mountain range.

The main goal of this paper is to improve the knowledge about accumulation conditions in the high parts of the Karakoram, by adding information to the very scarce existing data basis. The analysis of potential source regions will provide additional insight into the general situation of accumulation events during the seasons in this region. Therefore we concentrate the analysis on the crucial topics: accumulation history at a specific site, location of source regions, and temporal variations of precipitation events. In order to provide information about accumulation conditions, snow and firn studies have been carried out in the accumulation basin of Urdok glacier in central Karakoram in June 2006. The results of these investigations are presented here in the context of the influence of the general atmospheric circulation system on the specific conditions in the Karakoram region. Based on NCEP/NCAR reanalysis data, trajectories have been calculated to identify the source region of precipitation events detected in the samples of the snow and firn layer. This analysis allows evaluating the significance of typical large scale meteorological situations for accumulation events.

\section{Area of Investigations}

The Karakoram is one of the highest mountain ranges in the world and part of the extensive Hindukush-KarakoramHimalaya (HKH) complex, separating the Indian subcontinent from the main part of Asia. The Karakoram mountain range extends between $35^{\circ}$ and $36^{\circ}$ North, and $72^{\circ}$ and $79^{\circ}$ East, and is mainly situated in Pakistan with some parts reaching into India and China. The total area of glacier cover varies between about $15000 \mathrm{~km}^{2}$ and $19000 \mathrm{~km}^{2}$, depending on the data source, the degree of accuracy, and also the area definition $[14,15]$. The Karakoram has the highest degree of glaciation outside of the Polar Regions, where especially the high elevation basins (above $5000 \mathrm{~m}$ a.s.l.) show almost a continuous glacier cover, resulting in long glacier tongues reaching down to elevations well below $4000 \mathrm{~m}$ (for some large glaciers even well below $3000 \mathrm{~m}$ a.s.l., e.g., Batura glacier and Pasu glacier at about $2560 \mathrm{~m}$ and $2580 \mathrm{~m}$, resp.). Central Karakoram around the high peaks of K2, Broad Peak, and the Gasherbrum group also forms the drainage divide (main divide) between the Indus river in the Southwest and the Yarkand river in the Northeast.

The Urdok glacier (total area of $64 \mathrm{~km}^{2}$ ) is on the northern slope of the main divide and drains into the Shaksgam river which joins the Yarkand river and finally ends in the Tarim basin (Figure 1). The glacier is divided into two main branches, where the longer one (23 km length) starts from a pass at about $5200 \mathrm{~m}$ a.s.l. in the Southeast, while the shorter branch (about $20 \mathrm{~km}$ length) originates from about $5700 \mathrm{~m}$ a.s.l. just below the precipice of the Gasherbrum III North face. Our comparison of different Landsat satellite images (L5 TM, L7 ETM, and LC8) of the past 15 years shows no noticeable change in the glacier snout position at about $4260 \mathrm{~m}$ elevation, which is probably connected to the extensive supraglacial debris cover of $62 \%$. Based on a cloud free Landsat LC8 image (Path 148, Row 35) of July 14, 2013, the Urdok glacier and its supraglacial debris cover were mapped manually, because this gives the best results. Along the western margin of the glacier six looped moraines are discernible which indicate a series of fast advances of the shorter branch in the past. 


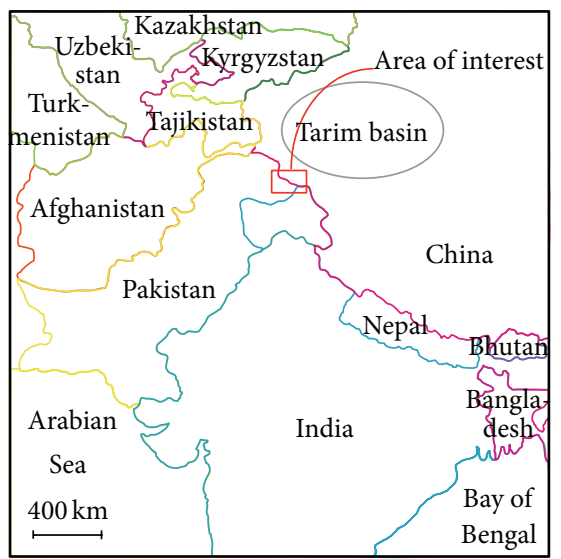

(a)

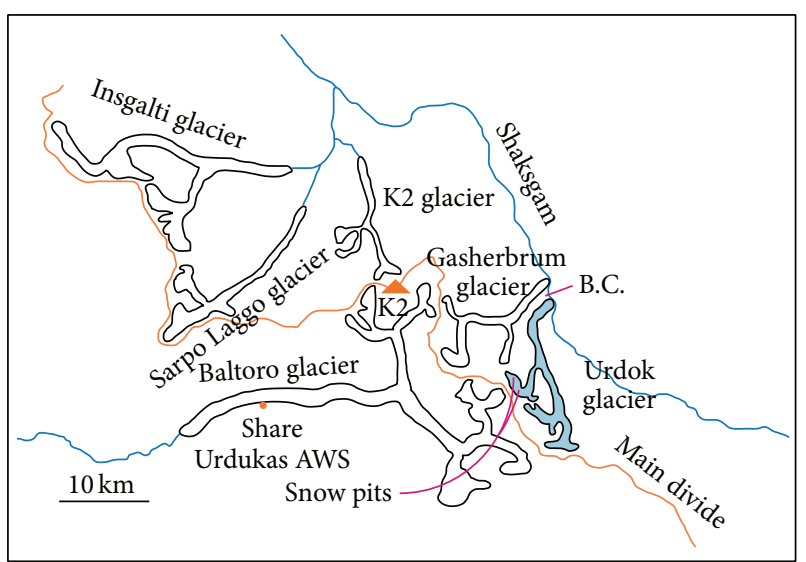

(b)

FIGURE 1: Location of Urdok glacier Northeast of the main divide of the Karakoram Range. The snow pits were situated in the northern accumulation basin.

The general weather situation of the Karakoram is characterized by two large scale circulation regimes: the cyclonic west wind circulation (WWC) and the South Asian monsoon (SAM). On the annual basis the WWC is dominating the weather pattern and probably accounts for the majority of the precipitation in the higher reaches of the Karakoram [16]. During the northern hemisphere winter the subtropical jet stream diverts cyclonic depressions towards Karakoram and northern India [13]. The central Asian mountain ranges (e.g., Pamir, Karakoram) form a barrier for the air transport which therefore is divided into a northern and southern branch (polar jet and subtropical jet). Due to the increasing warming of the land surface during spring the air transport is gradually diverted towards the North. The subtropical jet only sometimes extends along the southern margin of the $\mathrm{HKH}$ range, before it finally is established along the northern margin during the summer [13]. However, the higher layers of the atmosphere across the Karakoram are influenced by westerly winds for the entire year $[16,17]$. During summer a strong atmospheric depression develops across the Indian subcontinent due to the high temperature contrast between land and ocean surface. The strong pressure gradients generate continuous SW winds which transport large amounts of humidity towards the mountain ranges in the North. The additional depression above the Tibetan highlands intensifies this situation [18]. As a consequence very strong precipitation events occur during July and August on the Indian subcontinent stretching into the mountain ranges of HKH. In the interior of the Karakoram, the highest precipitation occurs, however, during early spring, when the subtropical jet stream becomes gradually unstable [19]. The contribution of the SAM to the total precipitation is still not very well known in this region, but its influence decreases from South to North [20, 21]. Wake [13] found indications for precipitation events influenced by monsoon incursions as far North as Biafo glacier in Central Karakoram from the analysis of snow pits and shallow firn cores.

\section{Data Collection and Analysis}

3.1. Glaciological Data. We present results from two snow pits from the accumulation zone of Urdok glacier at the Northeastern margin of the Karakoram, sampled in mid-June 2006 (Figure 1). The snow pits are situated in the western accumulation basin of the glacier at $5250 \mathrm{~m}$ and $5400 \mathrm{~m}$ elevation, respectively (Figure 1). To the West and to the South the locations are shaded by the high mountain ridges of the Gasherbrum group, while the glacier basin is rather open to the North, East, and Southeast. However, the area of the snow pits is not influenced by avalanches. The two pits were excavated to a depth of $225 \mathrm{~cm}$ (at $5350 \mathrm{~m}$ elevation) and $249 \mathrm{~cm}$ (at $5400 \mathrm{~m}$ elevation) and snow samples retrieved from $6 \mathrm{~cm}$ intervals for the determination of density and the analysis of the stable isotope ${ }^{18} \mathrm{O}$, as well as mineral dust (Figure 2). Due to logistic restrictions, the samples had to be melted in the field and transported in liquid conditions to the labs in Europe. In addition the stratigraphy of the snow/firn column was documented, focusing on the occurrence of ice and dust layers. The snow surface showed no signs of melt during the time of field work, indicating that the summer melt season had not yet started at this altitude and the winter snow was still preserved in the snow pits. Frequent ice layers in the pits, however, demonstrated that single melt events may occur at any time of the year. The content of the stable oxygen isotope ${ }^{18} \mathrm{O}$ and the mineral dust composition were analyzed at the liquid samples at the Alfred-Wegener Institute, Helmholtz Center for Polar and Marine Research at Bremerhaven, Germany, and the Paul Scherrer Institute at Villigen, Switzerland, respectively.

The isotope content $\delta^{18} \mathrm{O}$ was measured by a Finnigan DeltaS mass spectrometer and is given with respect to the Vienna Standard Mean Ocean Water (VSMOW). The isotopic composition of precipitation is related to the air temperature at which the atmospheric water vapour condensates [22]. Therefore, the relative stable isotope concentration $\delta^{18} \mathrm{O}$ in 




FIGURE 2: Photograph of snow pit 2 of 15.06.2006. Clearly visible are the prominent dust layers.

snow or ice is a good means to reconstruct air temperature variations in the past.

Mineral dust is usually deposited by precipitation events, sometimes also as fallout from the atmosphere after heavy storm events in the source region. The concentration and relative occurrence of rare earth elements (REE) can be used as a marker for the determination of source regions with special geological provenances [23]. Based on samples from possible source regions (PSA), a principal component analysis (PCA) was carried out in order to determine the potential source region of the dust extracted from the snow samples [24].

In order to connect the information from the snow pits with the local meteorological conditions, a simple weather station was installed at the base camp close to the glacier terminus, at $4200 \mathrm{~m}$ elevation. This station collected data about air temperature, relative humidity, wind speed, and precipitation during the period of field work from June 8, 2006, until June 18, 2006. Data collection was based on a fiveminute sampling interval and the data were subsequently transformed to hourly mean values. Air temperature is measured in a shielded but nonventilated housing by a thermistor element, while precipitation is quantified by a nonheated tipping bucket system. The precipitation measurements were in fact not necessary, because no precipitation event happened during the ten days of field work at the base camp. The main purpose of collecting these data was to determine the relative relationship between the local meteorological conditions and the conditions at the closest automatic weather station (SHARE Urdukas AWS), at $4022 \mathrm{~m}$ elevation, West of the main divide in about $47 \mathrm{~km}$ distance (39 km from the snow pits). From this station hourly data of the main meteorological parameters are available for most of the time since its installation in summer 2004 ( http:// www.evk $2 \mathrm{cnr}$.org/cms/en/share/monitoring-stations). The AWS at Urdukas is maintained by the SHARE Geo Network of Ev-K2-CNR in Italy (stations specifications can be found at http://www.stations.evk2cnr.org/SHARE_DB/ATMOSPHERE\% 20AND \% 20CLIMATE/ ASIA/PAKISTAN/Urdukas/ METADATA/). Air temperature is measured in a shielded but naturally ventilated housing by a PT-100 type sensor (LSI_Lastem DMA570) with an accuracy of $0.1^{\circ} \mathrm{C}$. The rain gauge (LIS-Lastem DQA035) is based on a tipping bucket principle with a nonheated collector and a described accuracy of better than $2 \%$ for precipitation of less than $3 \mathrm{~mm} / \mathrm{min}$. The standard meteorological parameters are collected as hourly mean values since June 17, 2004.

3.2. Atmospheric Data. In addition to the field data, meteorological reanalysis data from NCEP/NCAR [25] were used to interpret the results from the snow pit observations in a regional and global circulation context. These data are available at 6-hour intervals and have a spatial resolution of $2.5^{\circ}$. Using the HYSPLIT (hybrid single-particle Lagrangian integrated trajectory [26]) model from National Oceanic and Atmospheric Administration (NOAA) backward trajectories were calculated, based on the reanalysis data, for specific periods of precipitation events detected in the snow pits. This method helps to identify potential moisture source regions [27], although the accuracy is limited by the spatial and temporal representativeness of the meteorological input data. For our purpose we generally calculated backward trajectories for the last 14 days before the observed event and for three different elevation levels $(10 \mathrm{~m}, 2000 \mathrm{~m}$, and $5000 \mathrm{~m}$ above the snow pits at the time of deposition). In addition to the specific event based trajectories, also monthly and seasonal (DJF, MAM, JJA, SON) cluster trajectories were calculated for the period from 1996 until 2006. To complete the atmospheric input data sea level air pressure maps were produced as monthly means for the Asian region, also based on the NCEP/NCAR reanalysis data by using the LAS7 tool of the School of Ocean and Earth Science and Technology, University of Hawaii (http://apdrc.soest.hawaii.edu/las/getUI.do).

\section{Results}

For improving the knowledge of accumulation conditions in central Karakoram, we tried to answer the following questions:

What is the accumulation history at a specific site?

Is it possible to derive the source locations of precipitation events, in order to characterize the temporal distribution of accumulation?

Is there a long-term typical pattern of precipitation events, governing the accumulation in high altitudes?

4.1. On Site Accumulation History. The calculation of the total amount of accumulation (given in mm water equivalent) is rather straightforward, using the measured snow densities for each sample from the snow pits. We focus on pit 2 in this analysis, because the stratigraphy is almost identical between both pits and pit 2 reaches a larger depth (Figure 3 ).

The mean snow/firn density in pit 1 is $460 \mathrm{~kg} / \mathrm{m}^{3}$, compared to $430 \mathrm{~kg} / \mathrm{m}^{3}$ in pit 2. The snow density increases 


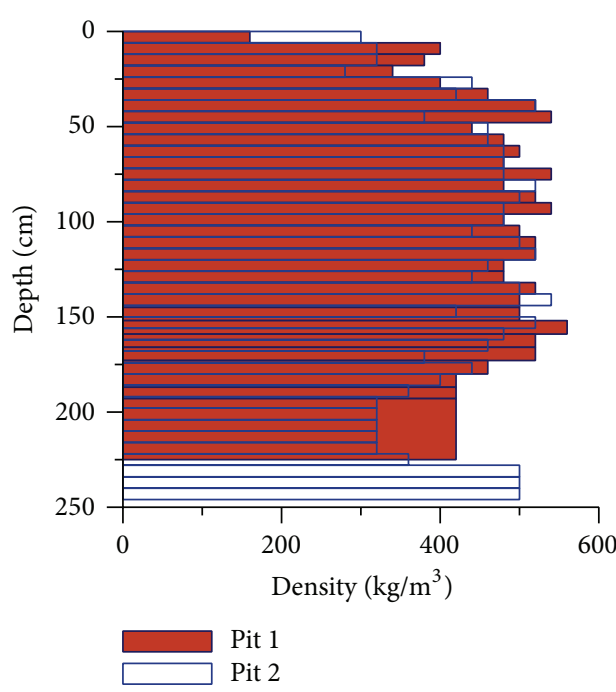

(a)

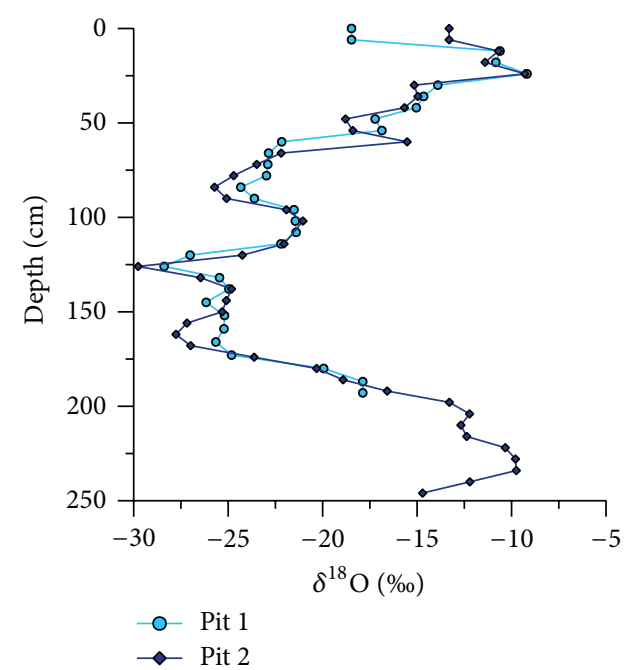

(b)

Figure 3: Comparison of the vertical density distribution in the two snow pits (a) and the $\delta^{18} \mathrm{O}$ values of the snow and firn samples (b).

considerably within the first $30 \mathrm{~cm}$ from the surface. This layer was deposited by precipitation/snow fall events during the spring of 2006. Further down the density is rather constant until $180 \mathrm{~cm}$ depth with a mean density of $502 \mathrm{~kg} / \mathrm{m}^{3}$ in pit 1 and $470 \mathrm{~kg} / \mathrm{m}^{3}$ in pit 2 . This sequence is interpreted as the winter accumulation 2005/06, while the layers between $180 \mathrm{~cm}$ and $230 \mathrm{~cm}$ depth show a lower density and thus probably originate from summer accumulation events during the previous year, 2005. Below $230 \mathrm{~cm}$ depth, the again increasing density in pit 2 (pit 1 ends at $230 \mathrm{~cm}$ ) indicates lower temperatures during deposition and therefore again winter conditions. A preliminary dating can be derived already from this very crude analysis, where the winter accumulation 2005/06 is situated between $30 \mathrm{~cm}$ and $180 \mathrm{~cm}$ depth, while the summer accumulation 2005 is found between $180 \mathrm{~cm}$ and $230 \mathrm{~cm}$ depth.

This time/depth relation can be improved by using the results from the $\delta^{18} \mathrm{O}$ analysis (Figure 3). It becomes clear that the snow in the snow pits was deposited during two warmer periods and one colder period, relating to the summer of 2005 , winter of 2005/06, and spring of 2006. The end of the winter $2004 / 05$ is also detectable in the samples of pit 2 . The $\delta^{18} \mathrm{O}$ values of both pits are very similar which confirms a homogeneous deposition in the upper regions of Urdok glacier.

We now try to refine the accumulation history based on the snow pit data and the weather station data. A comparison of the air temperature measurements between the local weather station at the glacier terminus and the SHARE Urdukas AWS, $47 \mathrm{~km}$ to the WSW, shows a high correlation, as can be expected for such distances. We postulate that, apart from local convective precipitation, major depression driven events occur across these short distances on both sides of the main divide. In this case the records of the SHARE Urdukas AWS can be used to reconstruct the accumulation history of the Urdok snow pits. Assuming a mean vertical lapse rate of $7.5^{\circ} \mathrm{C} / \mathrm{km}$ [28], taking into account the elevation difference between Urdukas and snow pit 2 of $1378 \mathrm{~m}$, and assuming snow accumulation for air temperatures lower than $1^{\circ} \mathrm{C}$ [29], precipitation will be deposited as snow at snow pit 2 for air temperatures lower than $11.3^{\circ} \mathrm{C}$ at Urdukas. The total precipitation amounts will be different between Urdukas and Urdok glacier, in dependence on the main direction of the depressions. However, the relative magnitude is very probably correlated, so that strong events at Urdukas will also produce larger depositions at Urdok glacier and vice versa. In addition to these assumptions, the stratigraphy of the snow pits (crystal size and layer hardness) and the relative relationship between $\delta^{18} \mathrm{O}$ values and air temperature were used for extracting snow fall events from the precipitation record of the Urdukas meteorological data. The comparison of the Urdukas temperature observations with the $\delta^{18} \mathrm{O}$ values from the snow pit provided a first rough snow depth time scale. Then the main precipitation events at Urdukas were related to layers in the snow pit which were recognized as major snow fall events. As a result, a time/depth relationship could be developed for the snow pit 2 at Urdok glacier which is directly related to the meteorological observations at the SHARE Urdukas AWS (Figure 4). The lowest layers in the snow pits have been deposited at the beginning of summer 2005, according to this relationship. The major amount of snow was deposited from the beginning of September 2005 until mid of May 2006, while during the period middle of October to end of January almost no accumulation occurred. During this period the Urdukas observations indicate only minor precipitation events and thus probably very little accumulation at the snow pit site.

The detailed time scale developed above enables us to derive the seasonal precipitation history (Table 1).

For the mass balance year 2005/06 a clear maximum in precipitation is observed during summer at Urdukas. This indicates that the monsoon had a considerable influence even 


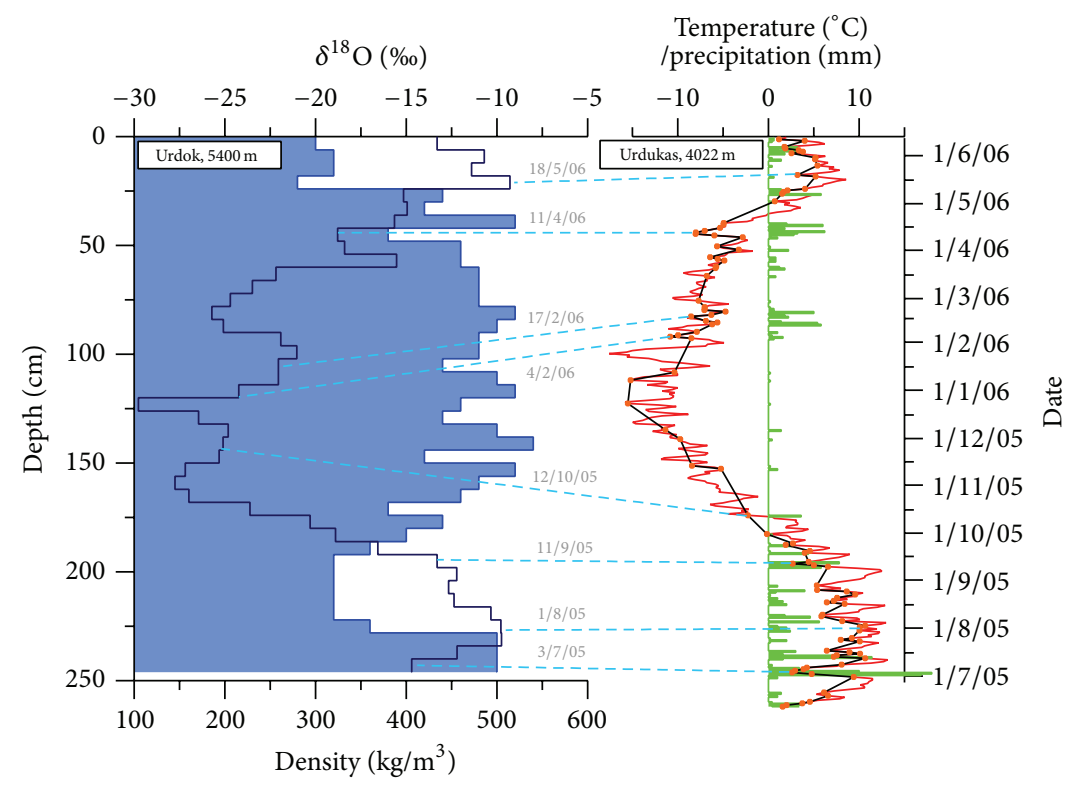

FIGURE 4: Comparison of the density and isotope measurements (left side) in pit 2 with the meteorological observations at Urdukas AWS. Air temperature is displayed as daily means (red solid) and daily mean temperature for days with precipitation (black line). Precipitation is given in mm w.eq. (green bars). The blue dashed lines indicate the temporal correlation of precipitation events between the meteorological observations and the snow pit samples.

TABLE 1: Summary of derived accumulation from the snow pit (Urdok glacier) and measured precipitation (Urdukas AWS) at the two sites.

\begin{tabular}{lcc}
\hline & Urdok glacier & Urdukas \\
\hline Winter (DJF) & $\sim 240 \mathrm{~mm}$ w.eq. & $29 \mathrm{~mm}$ w.eq. \\
Spring (MAM) & $\sim 330 \mathrm{~mm}$ w.eq. & $45 \mathrm{~mm}$ w.eq. \\
Summer (JJA) & $\sim 225 \mathrm{~mm}$ w.eq. & $125 \mathrm{~mm}$ w.eq. \\
Autumn (SON) & $\sim 160 \mathrm{~mm}$ w.eq. & $33 \mathrm{~mm}$ w.eq. \\
\hline Winter half year (23.9.-21.3.) & $\sim 520 \mathrm{~mm}$ w.eq. & $41 \mathrm{~mm}$ w.eq. \\
Summer half year (22.3.-22.9.) & $\sim 540 \mathrm{~mm}$ w.eq. & $191 \mathrm{~mm}$ w.eq. \\
\hline Annual sum & $\sim 1060 \mathrm{~mm}$ w.eq. & $232 \mathrm{~mm}$ w.eq. \\
\hline
\end{tabular}

this far into central Karakoram Mountains in 2006. This is also visible in the semiannual data, where the summer precipitation amounts to more than 4.6 times the value of the winter period. In contrast, the precipitation sums are much more regularly distributed on the Northeastern side of the divide, where the maximum is deposited during spring, while autumn is the driest season, but the differences are much smaller than at Urdukas. The semiannual values are almost identical between summer and winter. Despite the stronger influence of the monsoon total precipitation amounts are more than 4.5 times lower at the SHARE Urdukas AWS. The longer term meteorological observations at Urdukas (20042006) show that the summer precipitation maximum occurs regularly in this region (Figure 5).

4.2. Precipitation Origin. The stratigraphy of the snow pits revealed very distinct layers with high dust concentrations at various depths. Dust deposited by precipitation events allows

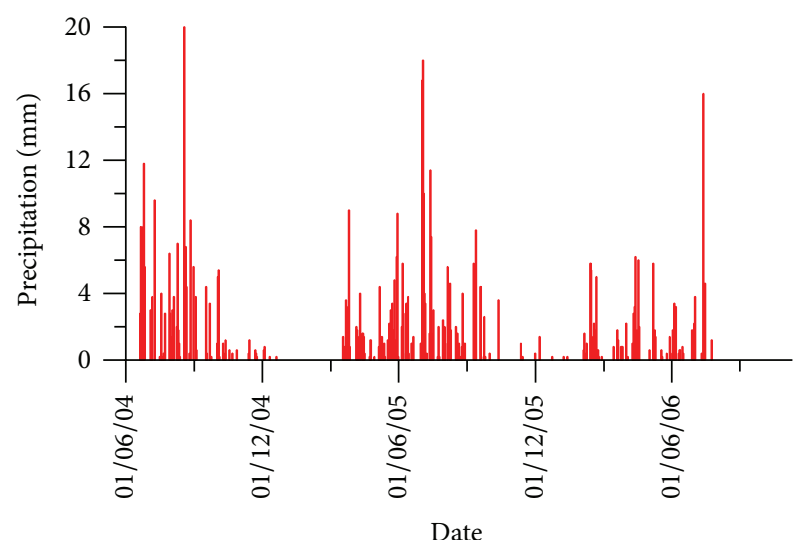

FIGURE 5: Daily precipitation recorded at SHARE Urdukas AWS between 2004 and 2006.

investigating the source region of the moisture. Three major dust layers were identified in the pit 2 in $30 \mathrm{~cm}, 144 \mathrm{~cm}$, and $228 \mathrm{~cm}$ depth. According to our time scale these layers coincide with May 2006, beginning of December 2005, and beginning of August 2005. The magnesium concentration in the snow samples, as a possible tracer of dust, is displayed in Figure 6. Two of the clearly visible dust layers form distinct peaks, while the dust layer at $144 \mathrm{~cm}$ depth is not that clear in the magnesium record but belongs to a longer series of higher concentrations which is connected with the period of late summer until early winter 2005. During the winter period (December 2005 until April 2006) magnesium concentrations are very low. Precipitation events are very rare 


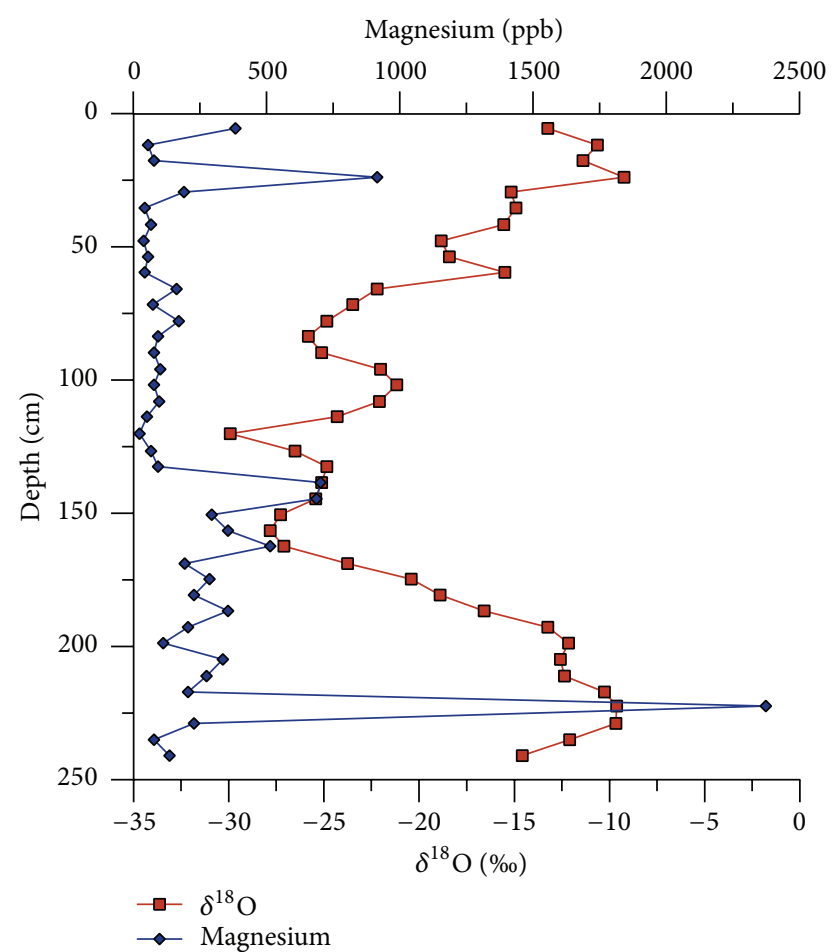

Figure 6: Comparison of the isotope signal and the magnesium concentration in the samples of pit 2 .

in December 2005 and January 2006, so that this period is not represented in the snow pit.

The principal component analysis of the RRE samples (Figure 7) reveals that dust in the samples with high dust/Mg concentration very likely originates from the dry regions of the Tarim basin, the Tibetan Plateau or the Mongolian deserts. Samples from the depth interval between $40 \mathrm{~cm}$ and $130 \mathrm{~cm}$ (February to May 2006) with the low dust concentration are displayed in the PCA plot at some distance of the Tarim basin samples. The large variability of the PCA for low dust concentration samples indicates that uncertainties are rather large for these samples, while all the high concentration samples very probably originate from western China (the source regions of the China samples in Figure 7, [23]).

The precipitation conditions can be further analyzed by investigating the regional and large scale meteorological characteristics. For the dates of the precipitation events, backward trajectories can be calculated, based on the reanalysis data. For this analysis, two weekly and monthly cluster means of near ground initial trajectories will be used, which cover the general conditions leading to the observed accumulation.

The first major dust event in August 2005 occurred during a situation where the general air transport was arriving at Urdok glacier from the Tarim basin, or the arid regions to the North (Figure 8). Air masses during this period always stayed rather low over ground which would enable the uptake and transport of dust from the surface. Wind speeds are moderate (3-4 km/h) during the entire observation period. The large scale pressure systems indicate higher winds along the main

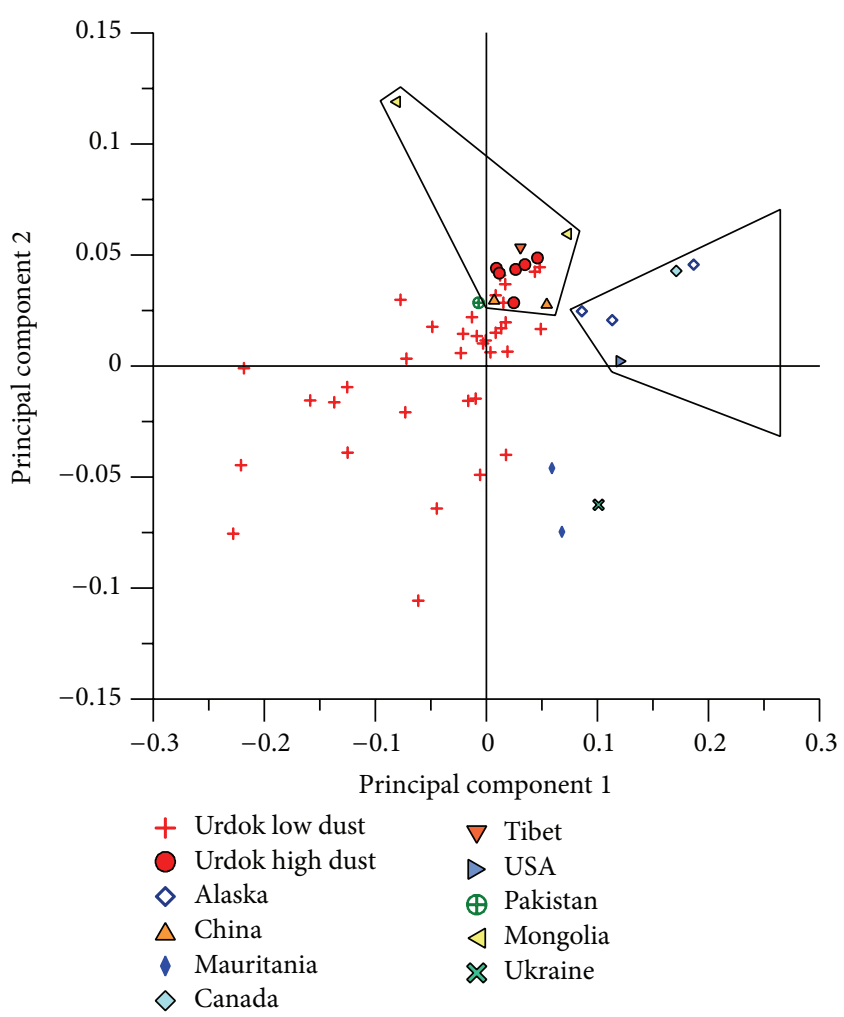

FIGURE 7: Principal component analysis of the mineral dust samples of pit 2 in comparison with the characteristics of different source regions [23]. Value regions from the arid central Asian basin and North America are shown as black polygons.

Karakoram Range from SE, driven by a high pressure system in the southern Tarim region, directing air masses from the Northwest towards the Karakoram main divide (Figure 8).

An event from mid-October 2005 documents high wind speeds close to the surface in the southern Tarim basin, with a general circulation turning from West to South and finally to East in the region of Urdok glacier (Figure 9). This event has the potential of mobilizing large dust amounts from this arid area and could be correlated with the dust layer in $144 \mathrm{~cm}$ depth.

The main dust event from May 2006 seems to be related to a general west wind situation with high wind speeds (Figure 10). In this situation with a high pressure system North of the Karakoram and a low pressure system above the mountains, the northern branch of the west wind system is considerably stronger. To the East of the high pressure cell, this air flow is redirected towards South and Southeast which results in easterly winds at Urdok glacier with a trajectory crossing the Tarim basin.

The situation during the low dust period (February to May 2006, 40-130 cm depth) is well characterized by the situation in February 2006 (Figure 11). During this time the westerly flow is dominating air mass transport from the eastern Mediterranean directly towards Urdok glacier. The southern branch of the jet stream dominates the circulation system during this period. In contrast to the low altitude 


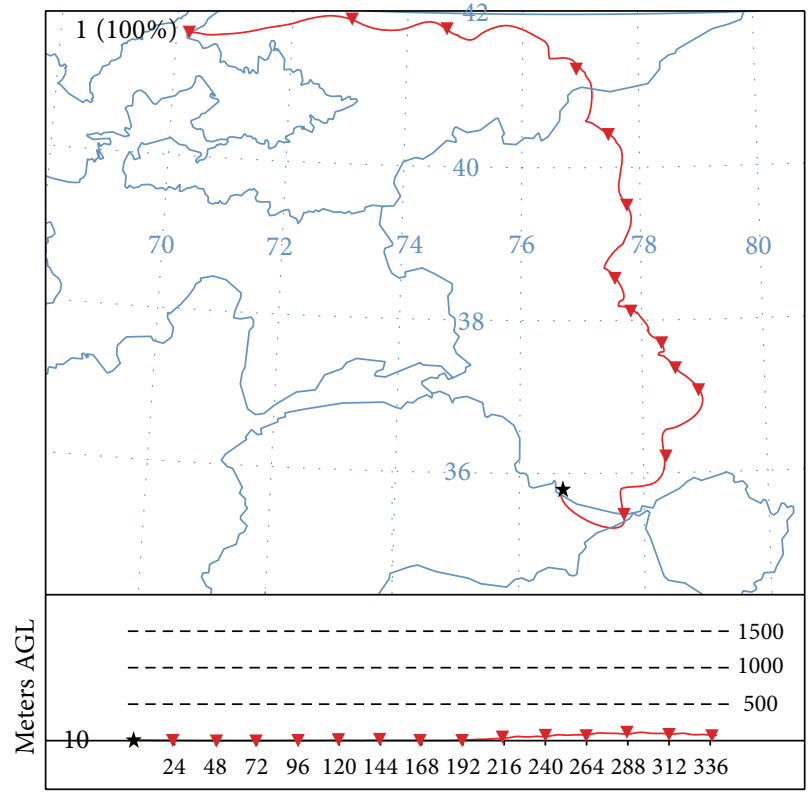

* Deposition location at $35.76 \mathrm{~N} 76.70 \mathrm{E}$

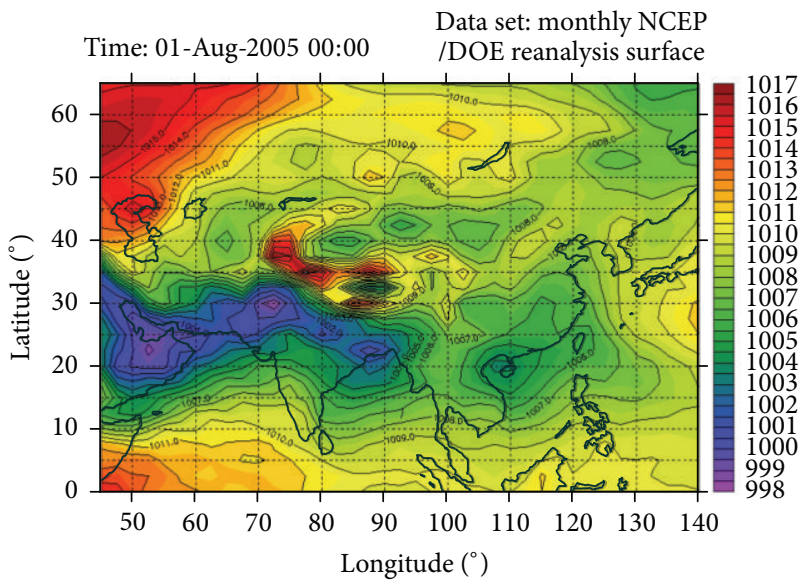

Sea level pressure $(\mathrm{mb})$

(a)

(b)

FIGURE 8: Cluster mean backward trajectory (16-day mean) for the deposition location of Urdok glacier (asterisk in the figure) in August 2005 derived from NCEP/NCAR reanalysis data with the HYSPLIT 7 simulation (a). The upper panel shows the travelled trajectory during two weeks, while the lower panel depicts the height above ground during this time period. (b) The mean large scale pressure distribution (reduced to sea level) is displayed for the same time period.

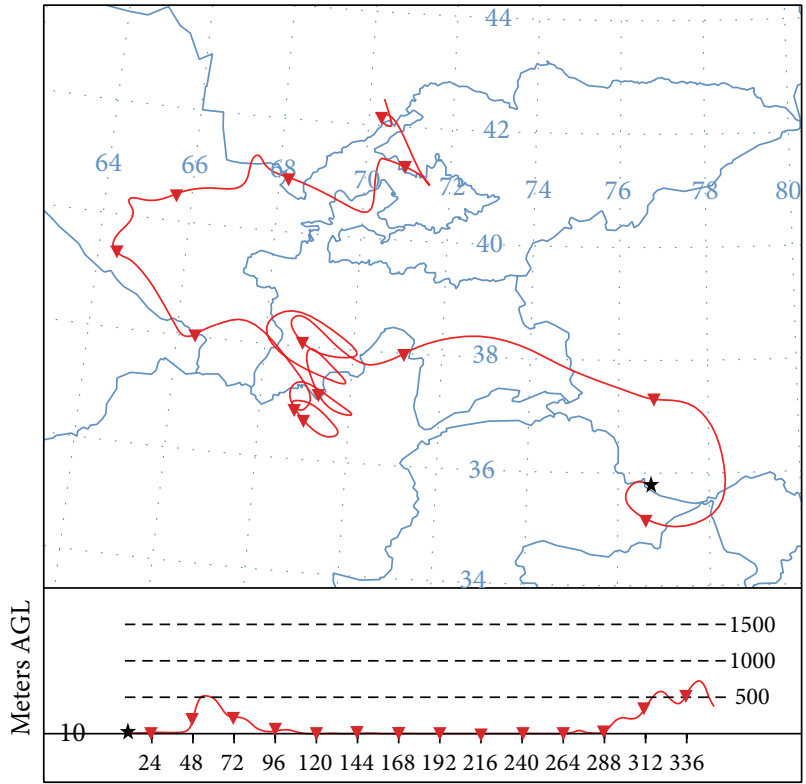

$\star$ Deposition location at $35.76 \mathrm{~N} 76.70 \mathrm{E}$

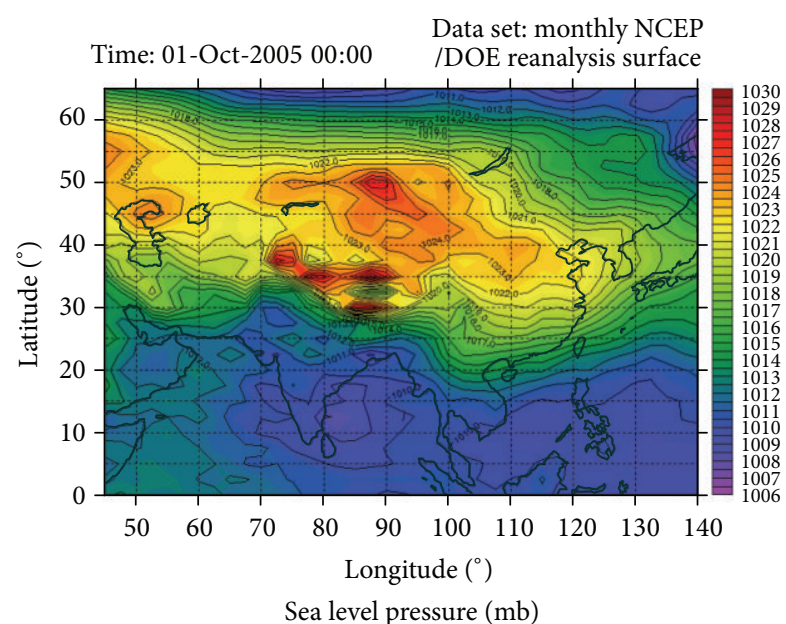

(b)

FIgURE 9: Two-week backward trajectory for 11. October 2005 (deposition date) at Urdok glacier (a). (b) The mean pressure distribution (reduced to sea level) is displayed for the first half of October 2005. 


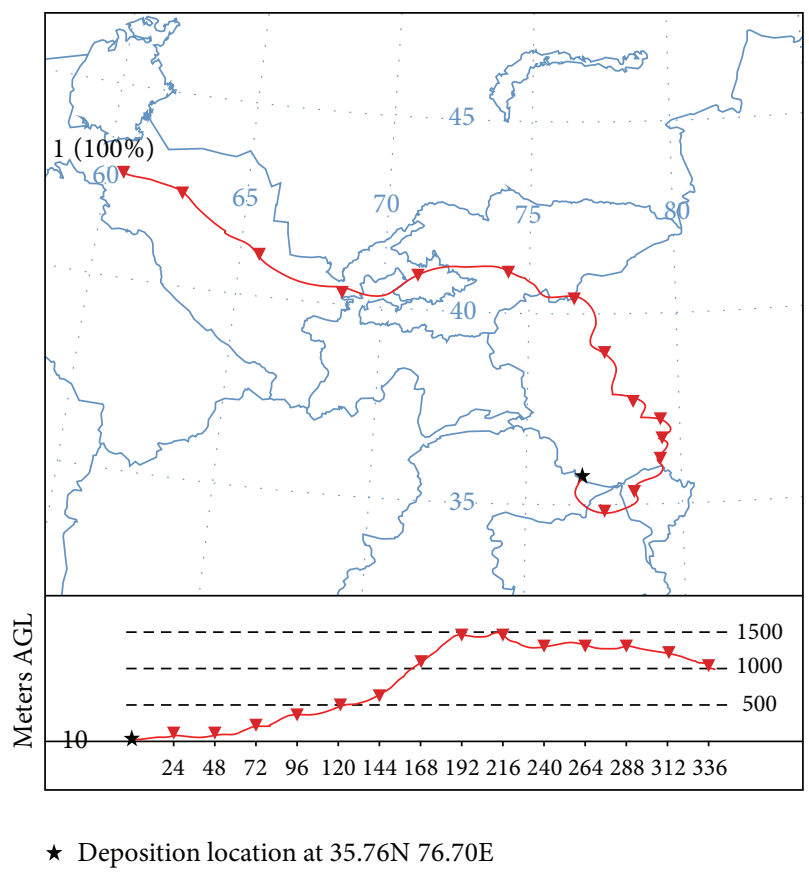

(a)

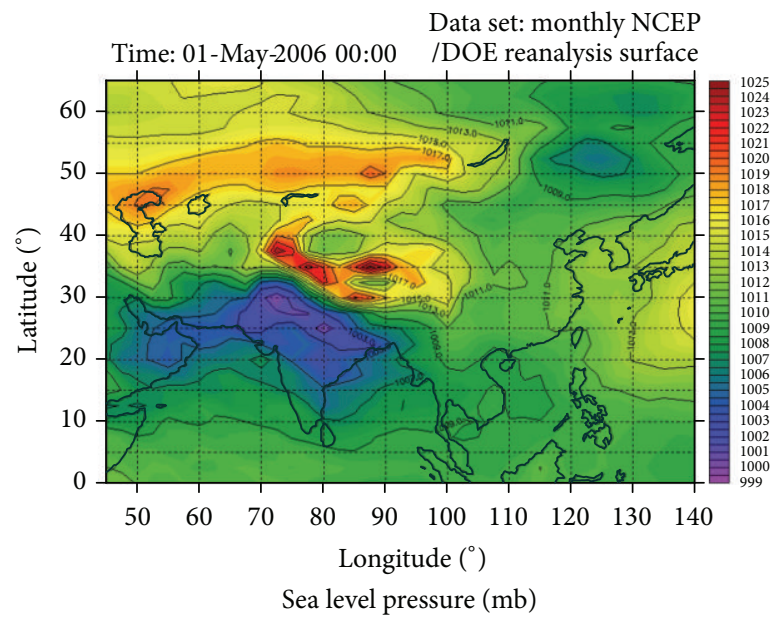

(b)

FIGURE 10: 16-day cluster mean backward trajectory for two weeks in May 2006 (a). (b) The mean large scale pressure distribution (reduced to sea level) is displayed for this period in May 2006.

transport during the dust events, the air masses arrive during this period from high altitudes. The pressure situation is characterized by an extensive high pressure cell above southern Siberia and Mongolia, while no large pressure gradients occur across the Karakoram (Figure 11).

4.3. General Accumulation Conditions. The analysis of the individual precipitation events documented in the snow pits indicates that general patterns exist, which favor accumulation of snow in the Karakoram. This was already investigated by several authors (e.g., [21, 30-32]). We aim at explaining our observations within this system. For this purpose eleven-year means were calculated for trajectories in the middle and upper troposphere $(2000 \mathrm{~m}$ and $5000 \mathrm{~m}$ above the glacier, resp.). During the entire period and all seasons westerlies dominate the air flow in the Karakoram region and wind velocities are higher during winter. In general also no influence of the monsoon is detected. There are singular exceptions, however. In August 2002 a strong SAM breach can be identified from the South/Southwest direction. Such events occur usually in August and are of variable magnitude. There is, however, no obvious trend towards stronger/weaker activity with time.

The near surface air flow shows more variations. In spring the westerlies arrive at Urdok glacier from a SW direction, indicating a dominance of the southern branch of the jet stream. Only occasionally a shift towards the northern branch is observed in May. This happens when the Tibetan high pressure cell becomes too strong during the end of spring.
Usually this shift occurs in late spring/early summer and surface winds then turn towards Northeast/East direction, originating from a deviation of the northern jet stream along the northern margin of the mountain range [33, 34]. Also the surface winds experience sometimes intrusions from the South during the monsoon period. This situation occurred, for example, in July 2005, which is clearly visible as strong precipitation at the Urdukas AWS (Figure 4).

The jet stream shifts its position from the northern to the southern branch during autumn, due to a progressive weakening of the Tibetan high pressure cell. Precipitation is thus mainly controlled by the westerlies in the higher and lower atmosphere. During summer the deviation of the westerlies in connection with the Tibetan high pressure leads to a general wind direction from NE to SE. During these periods high wind events can transport dust towards the high mountains, but precipitation amounts will remain moderate. Occasional shifts of the jet stream however have the potential of transporting larger amounts of humidity into the high glacierized regions [13, 19]. Monsoon driven precipitation occurs only as singular events and not every year but can bring considerable amounts of accumulation.

\section{Discussion}

The snow pit 2 in the northern accumulation basin of Urdok glacier covers roughly one year of accumulation from June 2005 until June 2006. The annual precipitation at this site results in $1060 \mathrm{~mm}$ w.eq., while recorded precipitation at the Urdukas AWS, almost $1400 \mathrm{~m}$ lower and Southwest of the 


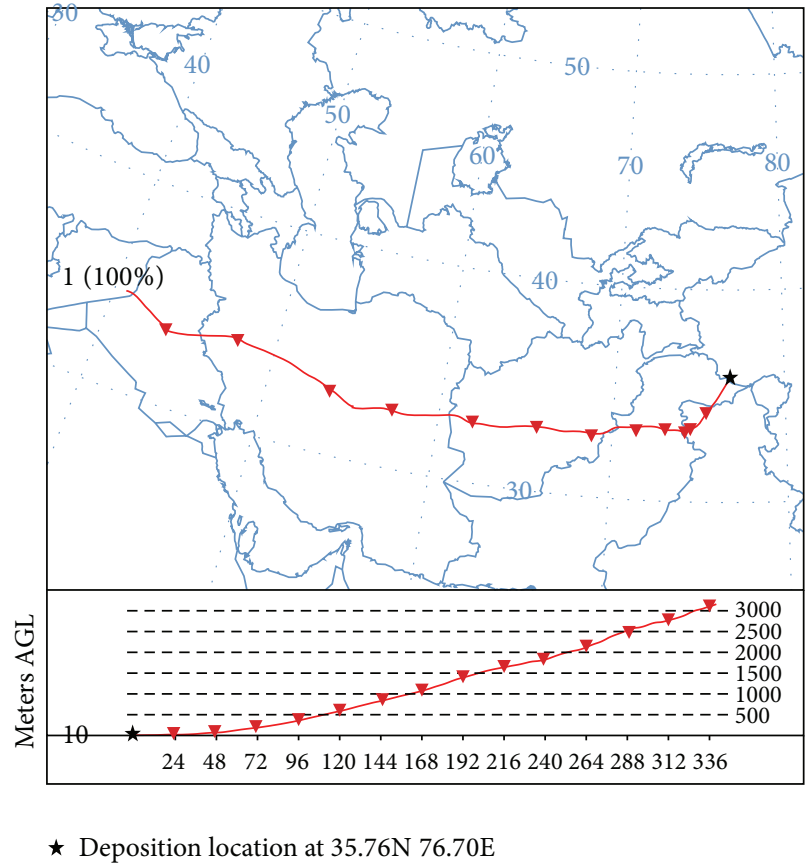

(a)

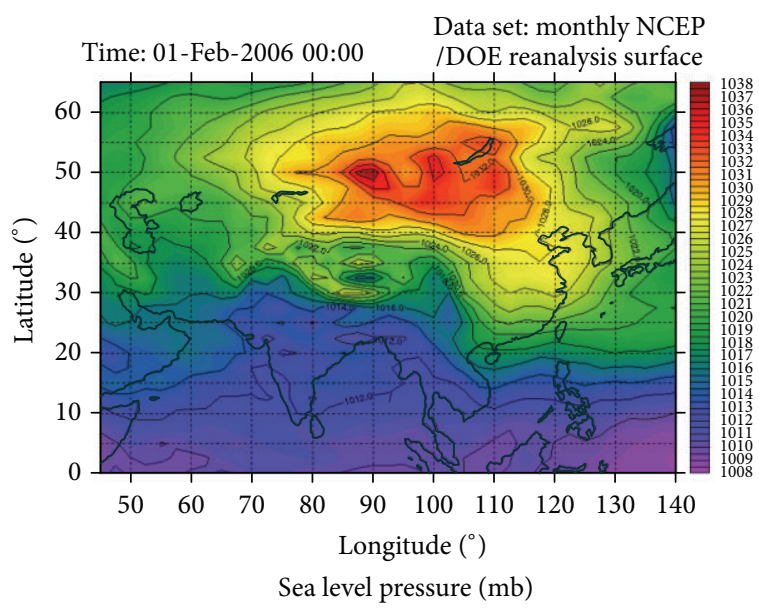

(b)

FIGURE 11: 17-day cluster mean backward trajectory for mid-February 2006 (a) and the accompagnying large scale pressure distribution (b).

main divide, shows only about $230 \mathrm{~mm}$ w.eq., roughly $22 \%$ compared to the high elevated site. The location of the snow pit is not affected by avalanches and wind erosion is not very likely due to the surrounding sheltering slopes. Therefore it can be assumed that the snow pit measurements represent a realistic and complete annual accumulation. The situation is more complex for the Urdukas AWS, where undercatch might be an issue, especially during winter, even though the total real precipitation will be not considerably higher than the measurements of the precipitation gauge.

Based on the annual precipitation amount of Table 1 , the vertical precipitation gradient between the two locations results in about $60 \mathrm{~mm}$ w.eq. for $100 \mathrm{~m}$ elevation change. It should be noted, however, that the two sites are situated Southwest and Northeast of the main divide and thus the vertical gradient is likely biased by spatial precipitation variability with respect to prevailing wind directions and moisture transport. Interannual variability is large at valley stations, as documented by data from Gilgit and Skardu (standard automatic WMO stations of Pakistan Meteorological Department), where the mean standard deviation is $34 \%$ and $49 \%$, respectively, for the period of 2000 until 2006. We assume that this is also valid for the high elevations sites.

Compared with the only other available measurements taken in the high regions of the Karakoram at Biafo/Hispar glaciers in the mid-1980s [13], our results of $1060 \mathrm{~mm}$ w.eq. annual accumulation are at the lower end of the observations for this altitude but well within the interannual variability based on the valley stations. The maximum annual precipitation based on these observations very probably occurs above $5000 \mathrm{~m}$ elevation [13]. Between 1983 and 1988 the accumulation in the elevation band of $4900 \mathrm{~m}$ to $5500 \mathrm{~m}$ in the Biafo/Hispar region was above $1000 \mathrm{~mm}$ w.eq. At Hispar Dome (5450 m elevation) the annual accumulation shows a strong variability $(700 \mathrm{~mm}$ to $2100 \mathrm{~mm}$ in $1983 / 84-$ $1985 / 86$ ), while the mean value results in about $1300 \mathrm{~mm}$ [13]. At these sites $45 \%$ of the accumulation is deposited between May and September. At Urdok glacier about 38\% of the accumulation occurs during the corresponding period which is rather similar. In contrast the long-term mean monthly observations (1959-2010) at the valley station of Gilgit ( $1460 \mathrm{~m}$ elevation) show that more than $52 \%$ of the annual precipitation occurs during this period of the year [35]. This demonstrates that the influence of the monsoon period on the total accumulation gradually reduces towards the main Karakoram divide. Summer precipitation (JJA), however, plays a much higher role at Urdukas, where single events can be strong (e.g., July 2, 2005), compared to Urdok glacier. This indicates that the main divide might work as a major barrier for monsoon driven incursions from the South. Comparable investigations in Nepal show that the total accumulation amount is similar, but the timing of the deposition is rather different, with the major accumulation occurring in spring and summer [4]. In contrast, the mean accumulation rate at Fedchenko glacier in the Pamir, for 2002 until 2005, was determined to be $1380 \mathrm{~mm}$ w.eq. and $2090 \mathrm{~mm}$ w.eq. at two sites $5206 \mathrm{~m}$ a.s.l. and $5365 \mathrm{~m}$ a.s.l., respectively [36]. The higher sample site was exposed towards the main precipitation direction, while the lower site was somewhat shaded at the leeward side. Higher precipitation 
values than those in central Karakoram probably occur due to the more open relief, while the seasonal distribution with the main precipitation events during late winter early spring is similar.

From the analysis of the trajectories and the large scale pressure distribution it follows that the precipitation events documented in the snow pit can be clearly related to characteristic situations. Besides some singular monsoon breaches, the snow accumulation at the pit location is characterized by humidity transport by the WWC. However, SAM incursions have the potential to transport considerable precipitation amounts up to central Karakoram (e.g., high precipitation at Urdukas, July 3, 2005, Figure 4). This is also in accordance with other observations [17]. In the case of the dominance of the northern branch of the jet stream the air flow might be directed across the Tarim basin and reaches Urdok glacier from Southeast. In this case the snow deposition coincides potentially with a high dust concentration, depending on the elevation of the air flow across the Tarim basin. High dust deposition on the glacier mainly originates in western China and occurs during late spring, summer, and autumn. During this period the air flow close to the glacier is dominated from East and Southeast directions. In general the overall circulation is characterized by westerlies at high altitudes, but regional pressure systems can account for direct transport of air, humidity, and dust from the Tarim basin and the central Asian mountain ranges. During winter the west wind circulation clearly controls the large scale air flow and the southern jet stream usually is the strongest. During this period humidity is transported from the Mediterranean to the Karakoram leading to frequent but weak precipitation events.

\section{Conclusions}

The combined investigations of snow pit samples and meteorological data result in a precipitation chronology for the higher reaches of central Karakoram for the year covered in the snow pits. Precipitation at the elevation above $5200 \mathrm{~m}$ occurs as snow also during the summer. Even though we found a large number of ice lenses in the snow/firn column, no extensive melt events and percolation were observed which would destroy the vertical chronology. The main accumulation amounts were deposited during late winter and spring, while the months November until January provided almost no accumulation. The analysis of the long-term atmospheric conditions shows that the mass balance year 2005/06 is rather typical and thus can be used to characterize the basic precipitation conditions. Our data fill a gap in the still scarce determination of high elevation accumulation in Asian mountains and the results fit the observations made earlier in the Karakoram [13]. The combination of these data indicates that there exists a negative gradient in accumulation from Southwest to Northeast, which would also explain the generally lower equilibrium line altitude in the Southwest compared to the mountains close to the main divide [35]. In general the SAM influence decreases towards the main divide and is rather small close to the divide on a long-term basis. Single events however can provide large amounts of accumulation. The analysis also proves that climatic data can be retrieved from snow pits at this altitude and can successfully be related to more general atmospheric information. However, sound information about the regional snow distribution requires similar measurements at more sites in the Karakoram in order to develop a reliable pattern of accumulation distribution across the mountain range. In addition, this study shows that carefully selected sites have the potential to be used for retrieving undisturbed, high resolution climate signals from ice cores in a region which lacks such information almost entirely at the moment.

\section{Conflict of Interests}

The authors declare that there is no conflict of interests regarding the publication of this paper.

\section{Acknowledgments}

Cordial thanks are given to York Schlomann (AWI) for conducting the ${ }^{18} \mathrm{O}$ measurements. EvK2-CNR gratefully provided meteorological data and financial support and organized the field work. Very constructive comments of an anonymous reviewer are gratefully accepted. They considerably improved the quality of the paper.

\section{References}

[1] D. R. Archer, N. Forsythe, H. J. Fowler, and S. M. Shah, "Sustainability of water resources management in the Indus Basin under changing climatic and socio economic conditions," Hydrology and Earth System Sciences, vol. 14, no. 8, pp. 1669$1680,2010$.

[2] G. Kaser, M. Großhauser, and B. Marzeion, "Contribution potential of glaciers to water availability in different climate regimes," Proceedings of the National Academy of Sciences of the United States of America, vol. 107, no. 47, pp. 20223-20227, 2010.

[3] A. Kääb, E. Berthier, C. Nuth, J. Gardelle, and Y. Arnaud, "Contrasting patterns of early twenty-first-century glacier mass change in the Himalayas," Nature, vol. 488, no. 7412, pp. 495498, 2012.

[4] U. Steinegger, L. N. Braun, G. Kappenberger, and G. Tartari, "Assessment of annual snow accumulation over the past 10 years at high elevations in the Langtang region," Snow and Glacier Hydrology, no. 218, pp. 155-165, 1993.

[5] J. Gardelle, E. Berthier, and Y. Arnaud, "Slight mass gain of Karakoram glaciers in the early twenty-first century," Nature Geoscience, vol. 5, no. 5, pp. 322-325, 2012.

[6] M. Rankl, C. Kienholz, and M. Braun, "Glacier changes in the Karakoram region mapped by multimission satellite imagery," The Cryosphere, vol. 8, no. 3, pp. 977-989, 2014.

[7] R. J. Braithwaite, "Positive degree-day factors for ablation on the Greenland ice sheet studied by energy-balance modelling," Journal of Glaciology, vol. 41, no. 137, pp. 153-160, 1995.

[8] R. Hock, "Temperature index melt modelling in mountain areas," Journal of Hydrology, vol. 282, no. 1-4, pp. 104-115, 2003.

[9] F. Pellicciotti, B. Brock, U. Strasser, P. Burlando, M. Funk, and J. Corripio, "An enhanced temperature-index glacier melt 
model including the shortwave radiation balance: development and testing for Haut Glacier d'Arolla, Switzerland," Journal of Glaciology, vol. 51, no. 175, pp. 573-587, 2005.

[10] M. Grabiec, "An estimation of snow accumulation on Svalbard glaciers on the basis of standard weather-station observations," Annals of Glaciology, vol. 42, no. 1, pp. 269-276, 2005.

[11] T. V. Schuler, P. Crochet, R. Hock, M. Jackson, I. Barstad, and T. Jóhannesson, "Distribution of snow accumulation on the Svartisen ice cap, Norway, assessed by a model of orographic precipitation," Hydrological Processes, vol. 22, no. 19, pp. 39984008, 2008.

[12] A. Senese, M. Maugeri, E. Vuillermoz, C. Smiraglia, and G. Diolaiuti, "Air temperature thresholds to evaluate snow melting at the surface of Alpine glaciers by degree-day models: the study case of Forni Glacier (Italy)," The Cryosphere Discussions, vol. 8, pp. 1563-1587, 2014.

[13] C. P. Wake, "Glaciochemical investigations as a tool for determining the spatial and seasonal variation of snow accumulation in the Central Karakoram, northern Pakistan," Annals of Glaciology, vol. 13, pp. 279-284, 1989.

[14] A. Arendt, T. Bolch, J. G. Cogley et al., Randolph Glacier Inventory [v2. 0]: A Dataset of Global Glacier Outlines, Digital Media, Global Land Ice Measurements from Space, Boulder, Colo, USA, 2012.

[15] M. B. Dyurgerov and M. F. Meier, Glaciers and the Changing Earth System: A 2004 Snapshot, Institute of Arctic and Alpine Research, University of Colorado, Boulder, Colo, USA, 2004.

[16] H. J. Fowler and D. R. Archer, "Conflicting signals of climatic change in the upper Indus Basin," Journal of Climate, vol. 19, no. 17, pp. 4276-4293, 2006.

[17] B. Bookhagen and D. W. Burbank, "Toward a complete Himalayan hydrological budget: spatiotemporal distribution of snowmelt and rainfall and their impact on river discharge," Journal of Geophysical Research: Earth Surface, vol. 115, no. 3, pp. 2003-2012, 2010.

[18] D. G. Hahn and S. Manabe, "Role of mountains in South Asian monsoon circulation," Journal of the Atmospheric Sciences, vol. 32, no. 8, pp. 1515-1541, 1975.

[19] S. Weiers, Zur Klimatologie des NW-Karakorum und angrenzender Gebiete. Statistische Analysen unter Einbeziehung von Wettersatellitenbildern und eines Geographischen Informationsystems (GIS), vol. 92 of Bonner Geographische Abhandlungen, Geographisches Institut, Universität Bonn, Bonn, Germany, 1995.

[20] S. Weiers, "Wechselwirkungen zwischen sommerlicher Monsunaktivität und außertropischer Westzirkulation in den Hochgebirgsregionen Nordpakistans," Petermanns Geographische Mitteilungen, vol. 142, pp. 85-104, 1998.

[21] D. R. Archer and H. J. Fowler, "Spatial and temporal variations in precipitation in the Upper Indus Basin, global teleconnections and hydrological implications," Hydrology and Earth System Sciences, vol. 8, no. 1, pp. 47-61, 2004.

[22] W. Dansgaard, "Stable isotopes in precipitation," Tellus, vol. 16, pp. 436-468, 1964.

[23] A. Svensson, P. E. Biscaye, and F. E. Grousset, "Characterization of late glacial continental dust in the Greenland Ice Core Project ice core," Journal of Geophysical Research D: Atmospheres, vol. 105, no. 4, pp. 4637-4656, 2000.

[24] C. Stenger, H. W. Gäggeler, C. Mayer, and M. Schwikowski, "Trace element analysis with CRI-ICP-MS," Annual Report of the Laboratory for Radiochemistry and Environmental Chemistry, PSI, 2006.
[25] R. Kistler, E. Kalnay, W. Collins et al., "The NCEP-NCAR 50year reanalysis: monthly means CD-ROM and documentation," Bulletin of the American Meteorological Society, vol. 82, no. 2, pp. 247-267, 2001.

[26] R. R. Draxler and G. D. Hess, "An overview of the HYSPLIT_4 modelling system for trajectories, dispersion and deposition," Australian Meteorological Magazine, vol. 47, no. 4, pp. 295-308, 1998.

[27] K. E. Sinclair and S. J. Marshall, “Temperature and vapourtrajectory controls on the stable-isotope signal in Canadian Rocky Mountain snowpacks," Journal of Glaciology, vol. 55, no. 191, pp. 485-498, 2009.

[28] C. Mihalcea, C. Mayer, G. Diolaiuti, A. Lambrecht, C. Smiraglia, and G. Tartari, "Ice ablation and meteorological conditions on the debris-covered area of Baltoro glacier, Karakoram, Pakistan," Annals of Glaciology, vol. 43, pp. 292-300, 2006.

[29] M. B. Rohrer and L. N. Braun, "Long-term records of snow cover water equivalent in the Swiss Alps 2. Simulation," Nordic Hydrology, vol. 25, no. 1-2, pp. 65-78, 1994.

[30] M. Winiger, M. Gumpert, and H. Yamout, "KarakorumHindukush-western Himalaya: Assessing high-altitude water resources," Hydrological Processes, vol. 19, no. 12, pp. 2329-2338, 2005.

[31] D. Bocchiola and G. Diolaiuti, "Recent (1980-2009) evidence of climate change in the upper Karakoram, Pakistan," Theoretical and Applied Climatology, vol. 113, no. 3-4, pp. 611-641, 2013.

[32] F. Maussion, D. Scherer, T. Mölg, E. Collier, J. Curio, and R. Finkelnburg, "Precipitation seasonality and variability over the Tibetan Plateau as resolved by the high Asia reanalysis," Journal of Climate, vol. 27, no. 5, pp. 1910-1927, 2014.

[33] P. Koch, H. Wernli, and H. C. Davies, "An event-based jetstream climatology and typology," International Journal of Climatology, vol. 26, no. 3, pp. 283-301, 2006.

[34] R. Schiemann, D. Lüthi, and C. Schär, "Seasonality and interannual variability of the westerley jet in the Tibetan Plateau region," Journal of Climate, vol. 22, no. 11, pp. 2940-2957, 2009.

[35] K. Hewitt, Glaciers of the Karakoram Himalaya, Glacial Environments Processes, Hazards and Resources, Springer, Dordrecht, The Netherlands, 2014.

[36] V. B. Aizen, P. A. Mayewski, E. M. Aizen et al., "Stable-isotope and trace element time series from Fedchenko glacier (pamirs) snow/firn cores," Journal of Glaciology, vol. 55, no. 190, pp. 275291, 2009. 

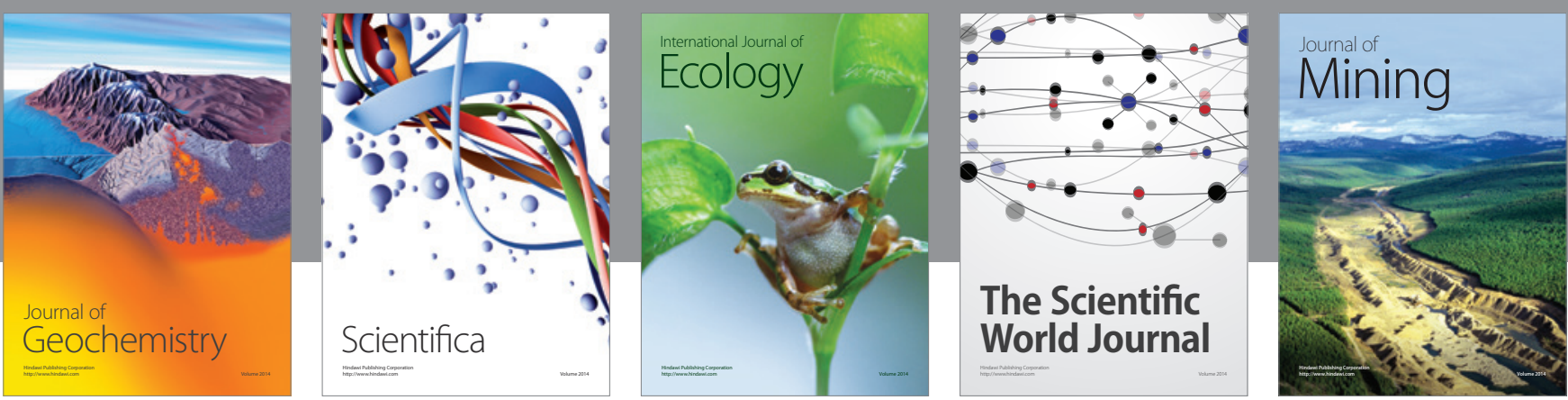

The Scientific World Journal
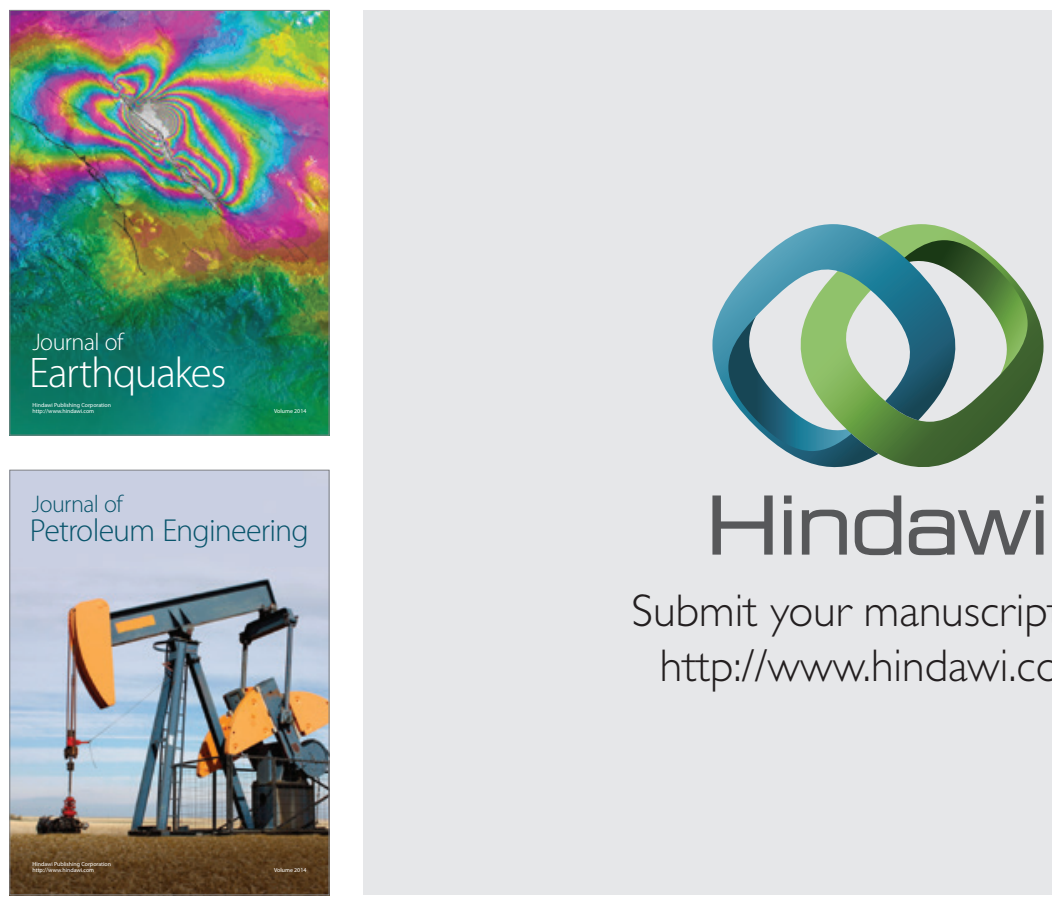

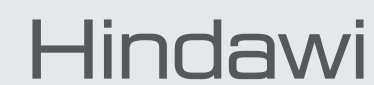

Submit your manuscripts at

http://www.hindawi.com
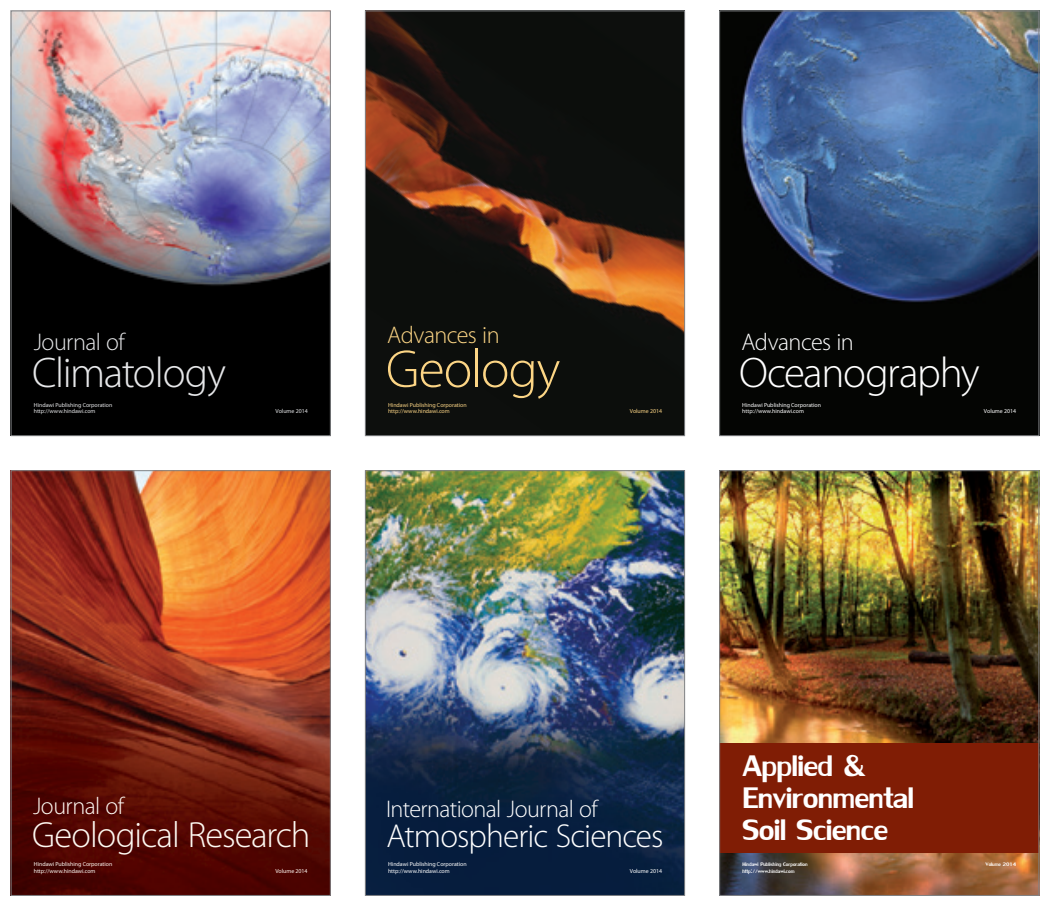
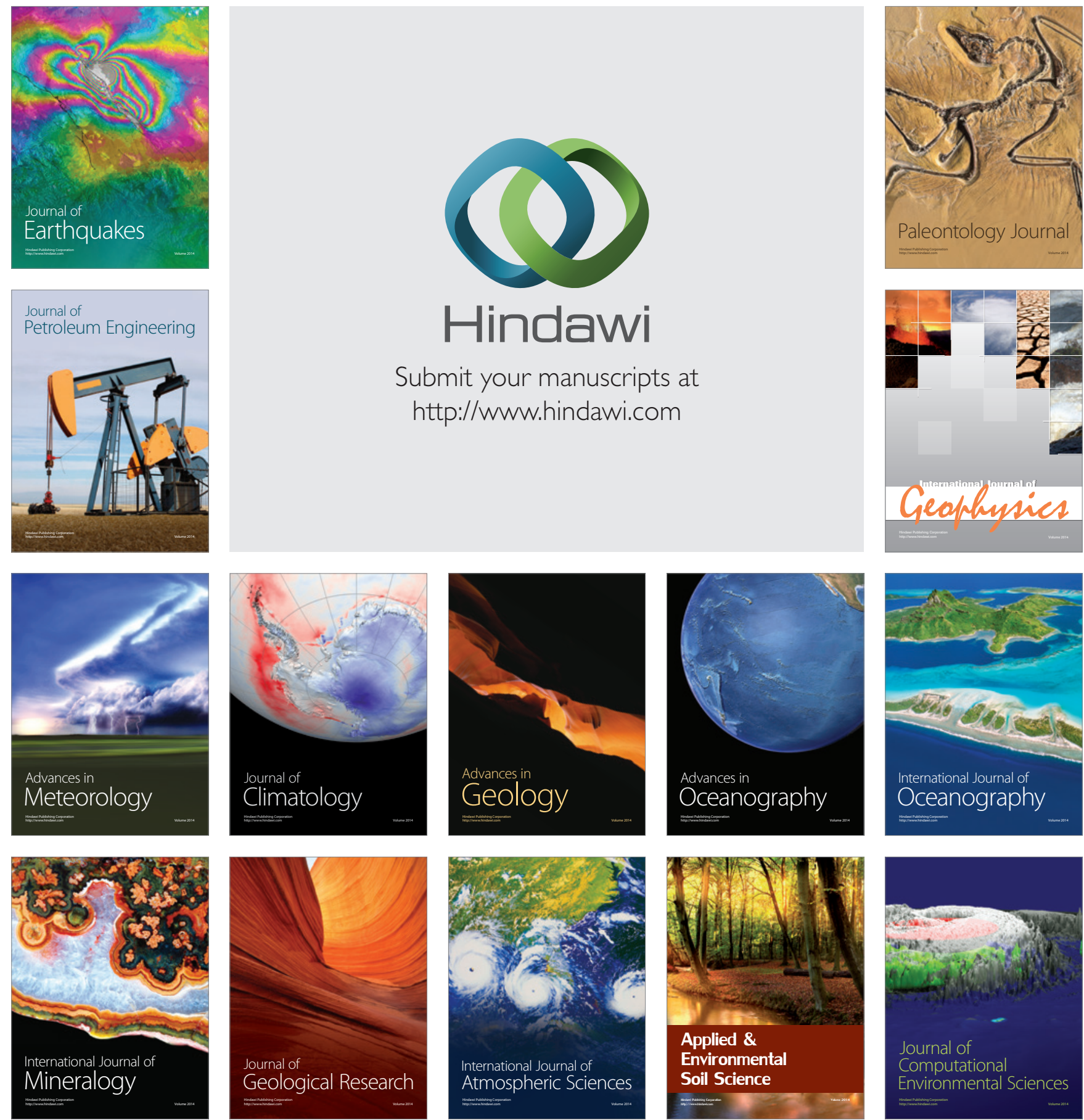